\title{
Can Community Policing Increase Residents' Informal Social Control? Testing the Impact of the Chicago Alternative Policing Strategy
}

Robert M. Lombardo

Loyola University Chicago

Chistopher M. Donner

Loyola University Chicago, cdonner@luc.edu

Follow this and additional works at: https://ecommons.luc.edu/criminaljustice_facpubs

Part of the Criminology and Criminal Justice Commons

\section{Author Manuscript}

This is a pre-publication author manuscript of the final, published article.

\section{Recommended Citation}

Lombardo, Robert M. and Donner, Chistopher M.. Can Community Policing Increase Residents' Informal Social Control? Testing the Impact of the Chicago Alternative Policing Strategy. Police Practice and Research, 19, 5: 427-442, 2017. Retrieved from Loyola eCommons, Criminal Justice \& Criminology: Faculty Publications \& Other Works, http://dx.doi.org/10.1080/15614263.2017.1405265

This Article is brought to you for free and open access by the Faculty Publications and Other Works by Department at Loyola eCommons. It has been accepted for inclusion in Criminal Justice \& Criminology: Faculty Publications \& Other Works by an authorized administrator of Loyola eCommons. For more information, please contact ecommons@luc.edu.

\section{cc) (i) $\ominus$}

This work is licensed under a Creative Commons Attribution-Noncommercial-No Derivative Works 3.0 License. (c) 2017 Informa UK limited, trading as Taylor \& Francis Group 


\begin{abstract}
This study examines whether community policing can build informal social control. Specifically, this paper assesses the impact of the Chicago Alternative Policing Strategy (CAPS) in Chicago neighborhoods. The data for this research are drawn from both the Community Survey of the Project on Human Development in Chicago Neighborhoods (PHDCN) and the CAPS Prototype Panel Survey. Bivariate and multivariate methods are used to analyze data gathered from 8,782 residents nested within 343 neighborhood clusters. Initially, community policing was found to increase informal social control, but this effect was rendered nonsignificant after controlling for theoretically and empirically relevant variables. Several social (dis)organization variables, as well as satisfaction with policing services, yielded significant effects in a multilevel regression model. Further analysis found that the community policing effect on informal social control was mediated through satisfaction with the police. These findings indicate indirect support for the ability of community policing to build informal social control and suggest that general satisfaction with the police is important to neighborhood crime control strategies.
\end{abstract}

Keywords - Chicago Alternative Policing Strategy; community policing; informal social control 


\section{Introduction}

Community policing is a law enforcement philosophy based on the argument that police officers and private citizens, working together in creative ways, can help solve contemporary community problems related to crime, fear of crime, and social and physical disorder (Tronjanowicz, Kappeler, Gaines, and Bucqueroux, 1998). First echoed by one of Sir Robert Peel's principles that the police are the community and the community are the police, community policing has become one of the most widely adopted police strategies of the last thirty years. Community policing is so popular that by $2001,90 \%$ of all urban police departments in the U.S. reported employing fully trained community police officers (Hickman \& Reaves, 2001). It was a central component of the 1994 Crime Bill, and its continued implementation is one of the key recommendations made by the 2015 President's Task Force on $21^{\text {st }}$ Century Policing. The popularity of community policing, moreover, is not restricted to the United States. For example, police departments in the United Kingdom, Australia, South Africa-and many other parts of the world — have adopted it as their law enforcement philosophy, and several of these international efforts have been the focus of empirical research (e.g., Davis, Henderson, \& Merrick, 2003; Marks, Shearing, \& Wood, 2009).

Efforts at community policing have encompassed a number of broad strategies to reduce crime and disorder including asking citizens to assume responsibility for crime control by reporting crime promptly to the police, by cooperating as witnesses when crimes occur, and by working with police to come up with solutions to neighborhood crime and disorder problems. In order to ensure citizen cooperation, police have attempted to take responsibility for mobilizing individuals and organizations around crime prevention through various community police programs including community meetings that seek to increase favorable contacts between the 
police and the public. Many community policing scholars (Rosenbaum, 1987; Skogan, 1990;

Lyons, 1999) envision that these efforts will help to increase the inherent social control mechanisms that have been lost in neighborhoods besieged by crime and disorder. Described by Rosenbaum (1987) as the community implant hypothesis, this argument has, unfortunately, been the subject of very little empirical research.

In addressing this gap, this study tests the ability of community policing to strengthen informal social control in Chicago neighborhoods. Drawing from the community implant hypothesis, the current research analyzes PHDCN and CAPS data to examine whether community policing in Chicago contributes to increased informal social control. This study begins with a review of pertinent literature, is followed by a series of statistical analyses to test the impact of CAPS on informal social control, and concludes with a discussion of the findings and their implications for research and policy.

\section{Literature Review}

The literature review is divided into three sections. Section one reviews notable research on community policing. Section two details the Chicago Alternative Policing Strategy, and section three reviews research on building informal social control in community areas.

\section{Community Policing}

Community policing, at its heart, entails greater community involvement in the identification of crime and disorder problems, and it encourages stronger police-community relationships to help prevent and control crime. Police departments have attempted to institute community policing in a number of ways including foot patrol, bicycle patrol, police substations, citizen police academies, community meetings, newsletters, surveys, crime analysis, and working with other government agencies to find nontraditional solutions to crime problems (for a 
review of these strategies, see Weisburd \& Eck, 2004). How it looks in practice varies from jurisdiction to jurisdiction in response to the individual needs of each community (e.g., Mastrofski \& Ritti, 2000).

Although the overarching philosophy of community policing is fairly homogenous as outlined above, there are many different community policing strategies, thus, it is difficult for researchers and practitioners alike to agree on a singular conceptualization. Accordingly, the Committee to Review Research on Police Policy and Practices of the National Research Council (Skogan \& Frydl, 2004) has argued that community policing is simply too amorphous a concept to submit to empirical evaluation. In an attempt to provide some understanding of community policing, Scott (2002) argued that most community policing programs share three common elements: organizational change, problem solving, and efforts to mobilize community residents to address problems on their own [authors’ emphasis].

Community policing has become so popular that it has been described as the "primary formulation” for the provision of police service in the United States (Oliver, 2000). Since 1995, the U.S. Department of Justice Office of Community Oriented Policing Services (COPS) has invested $\$ 14$ billion in support of community policing. This investment includes grants awarded to more than 13,000 state and local law enforcement agencies, training of more than 500,000 law enforcement officers and local leaders, and funding the development of numerous technical assistance resources that seek to increase the body of knowledge available on critical community policing issues (Department of Justice, 2016).

Despite the widespread use of community policing, there is no conclusive research supporting the ability of community policing to reduce crime in neighborhood areas (for reviews, see e.g., Crowl, 2017; Gill, Weisburd, Telep, \& Bennett, 2014). For example, Sozer and Merlo’s 
(2013) study of American police departments found that community policing worked better to reduce crime in small cities than it did in large cities. Studying foot patrol in Boston, Bowers and Hirsch (1987) found no reliable evidence that foot patrol impacted order maintenance or crime. MacDonald (2002) concluded, in his research on 164 American cities, that community policing had little effect on the control of violence, but that proactive policing strategies were directly related to reductions in violent crime over time. Nor have popular community policing activities, such as storefront offices and community meetings, been found to reduce crime (Weisburd \& Eck, 2004). Other studies, however, have shown that community policing can reduce fear of crime (Brown \& Wycoff, 1987), increase satisfaction with police (Lombardo, Olson, \& Stanton, 2010; Weitzer \& Tuch, 2005), and increase community cohesion and organization (Kerley \& Benson, 2000).

The fascination with community policing began to fade as police departments recognized their inability to reduce crime and began to implement intelligence-led policing, Compstat, and other technically-driven crime control strategies. In fact, an often-quoted article in the April 2004 issue of the FBI Law Enforcement Bulletin concluded that society should put an end to the era of community policing and engage, instead, in policing utilizing evidence-based practices from the last twenty years (Kerlikowske, 2004). Others argue, however, that such evidence-based practices would in fact be enhanced by incorporating them into a police department's community policing strategy (Scheider, Chapman, and Schapiro, 2009). These data-driven, sometimes aggressive, police strategies often had the unanticipated consequence of increasing tension between the police and the public as greater numbers of citizens were subjected to police interrogation, particularly in minority communities. The simmering conflict between the police and the community they served came to a head in Ferguson, Missouri during the summer of 2014 
when rioting broke out following a police-involved shooting. Responding to the incident in Ferguson, and other similar incidents around the country, President Barack Obama established the Task Force on $21^{\text {st }}$ Century Policing in an effort to strengthen the relationship between the police and the communities they serve. One of the major, yet broad, recommendations of the Task Force was greater emphasis on strengthening police-community relationships through community policing initiatives (President’s Task Force on $21^{\text {st }}$ Century Policing, 2015).

\section{The Chicago Alternative Policing Strategy}

The nation's largest community policing program is the Chicago Alternative Policy Strategy (CAPS) (Skogan \& Hartnett, 1997). The focus of CAPS is community mobilization. Residents are asked to watch over their neighborhoods and call the police when they see something wrong. Moreover, citizens are asked to report crime, broken windows, abandoned autos, and weed infested vacant lots, as well as loud teens and loitering gang members.

The model of community policing on which CAPS is based relies heavily on problemsolving at the neighborhood level, which is supported by a variety of strategies, chief among them is a system of regular beat meetings (Chicago Community Policing Evaluation Consortium [CCPEC], 1995). These meetings are comprised of small groups of citizens and police officers who meet in school rooms, church basements, and other such locations throughout the city. The function of these meetings is to bring citizens and police officers together to work on solving community problems. Other CAPS strategies include: extensive training for both police and community to identify and solve neighborhood crime and disorder problems, more efficient use of city services that impact crime, and new technology to help police and residents target crime hot spots. 
The CAPS program has been subjected to a rigorous research agenda. The CCPEC studied the planning, implementation, and impact of CAPS over a ten-year period. Their research covered many diverse topics including police training, citizen involvement, problem solving, and beat meeting participation. In all, 31 evaluations were conducted investigating the effectiveness of the CAPS program (Institute for Public Policy Research, 2016). Like community policing generally, and in spite of fact that the CAPS program has been in existence since 1994, they conducted little empirical research exploring the ability of CAPS to build informal social control in community areas.

The argument that community policing research has not adequately tested the ability of police-community partnerships to build and sustain informal social control is widely accepted in the policing literature (e.g., Scott, 2002; Reisig \& Parks, 2004; Renauer, 2007). One of the main reasons for the lack of research is the limitations imposed by the available data. While the residents of the CAPS pilot districts were asked 128 questions about their community and the CAPS program, none of the questions measured informal social control (Skogan, 2004). The current study addresses this issue by using PHDCN data to test the impact of the CAPS program on this important variable. The use of PHDCN data is appropriate for several reasons, including that it measured informal social control, that it occurred at the same time as the CAPS pilot test, and that both data sets list the census tracts of the observations allowing the datasets to be linked. Building Informal Social Control and the Community Implant Hypothesis

Social control generally refers to the capacity of a group to regulate the conduct of its members. Formal social control is derived from written rules and laws and is enforced by the police and the courts, whereas informal social control is based on customs and social norms and is enforced by the citizenry. The question for community policing then becomes whether the 
police, working with the community, can influence informal social control in troubled areas. This strategy has been adopted by a number of police departments, including Chicago, as the basis of their community policing programs in the form of beat meetings and greater community involvement in problem solving activities, and is the basis of the community policing argument that citizens are co-producers of public safety.

The idea that police and citizens alike can contribute to social control in community areas is grounded in social disorganization theory, and researchers have long argued that one of the main reasons for high levels of crime is the lack of informal social control in community areas. Specifically, this line of reasoning argues that an increase in disorder and crime is a direct reflection of the inability of adults to control the delinquent activities of youth and the criminal activities of the adult community (e.g., Shaw \& McKay, 1942; Wilson, 1987; Sampson, Raudenbush, \& Earls, 1997). Social disorganization produces increases in crime via a lack of informal social control through a combination of weak social ties to others, an absence of community cohesion, and a lack of residents' social capital. Essentially, the willingness of local residents to intervene for the common good-depends in large part on conditions of mutual trust and solidarity among neighbors. This argument has been supported by research showing that communities tend to have lower crime rates when residents self-regulate through systems of informal social control (e.g., Sampson et al., 1997).

Rosenbaum (1987) proposed the “community implant” hypothesis as a way to help build and reinforce informal social control. It argues that informal social control can be embedded by collective citizen action in neighborhoods where social control is naturally weak or nonexistent. Described as “community building” by Mastrofski, Worden, and Snipes (1995), this approach is a process by which the police can strengthen the determination of citizens to build informal 
social control through community policing initiatives. Community policing advocates, such as Rosenbaum (1987), argue that if crime is the result of social disorganization, police departments should work to improve informal social control by strengthening community ties and by encouraging behaviors that provide a basis for regulating conduct.

While there is little empirical research testing the direct relationship between community policing and informal social control, there have been efforts to study the sources of informal social control in urban areas through concepts such as social cohesion, neighborhood activism, social capital, and neighborhood ties (e.g., Kerley \& Benson, 2000; Sampson et al., 1997; Silver \& Miller, 2004; Warner, 2007; Warner, 2014). For example, research by Kerley and Benson (2000), demonstrated that community policing strategies increased both community cohesion and organization in the city of Birmingham. Silver and Miller (2004) studied the sources of informal social control in Chicago utilizing the same PHDCN data used in this analysis; the authors concluded after conducting 7,061 in-person interviews that efforts at improving informal social control in urban neighborhoods should focus on improving police-community relations and local conditions that would lead residents to develop stronger attachments to their neighborhood. Research from Warner (2014), analyzing data from individuals within a southern U.S. city, found that social cohesion and faith in the police increased residents' positive attitudes towards informal social control efforts.

In an effort to provide direct evidence of the relationship between community policing and informal social control, Renauer (2007) analyzed survey data collected from 81 community organizations in Portland, Oregon. Controlling for neighborhood structural disadvantage, neighborhood fear of crime, social cohesion, and perceptions of government responsiveness, Renauer's results indicated that community policing efforts were not positively related to 
informal social control. ${ }^{1}$ Instead, the strongest predictors of informal social control were perceptions of neighborhood social cohesion and government responsiveness to neighborhoods (see also, Gill et al., 2014; Lombardo \& Lough, 2007).

\section{Current Study}

This study builds on previous research (e.g., Kerley \& Benson, 2000; Renauer, 2007) and utilizes Rosenbaum's (1987) community implant hypothesis as a conceptual framework to assess the impact of community policing on residents' willingness to engage in informal social control. The influence of CAPS is examined by analyzing data collected for the Project on Human Development in Chicago Neighborhoods (Earls, 1999). In this study, a quasi-experimental design was used to test the effects of CAPS on informal social control in Chicago neighborhoods. Though the current study employs a post-test only analysis of cross-sectional data, those community members who were interviewed were selected based upon a systematic random sampling design, while controlling for racial and ethnic composition and socioeconomic status (Earls \& Burka, 1997). Moreover, we employ multilevel linear modeling, which enabled the simultaneous estimation of both between- and within-neighborhood differences in residents' informal social control. We believe this methodological strategy improves upon methods used in prior research assessing the effect of community policing on informal social control.

\section{Methods}

\section{Data and Sample}

Data for this study came from two sources: (1) the Community Survey of the Project on Human Development in Chicago Neighborhoods (PHDCN-CS) and (2) the CAPS Prototype

\footnotetext{
${ }^{1}$ One reason why Renauer's (2007) study may have failed to find a relationship between community policing and informal social control is due to his methodology. His data collection utilized one neighborhood informant per neighborhood to provide an assessment of neighborhood social climate and police-resident relationships. He also used OLS regression to examine neighborhood social control, which is not able to detect both betweenneighborhood and within-neighborhood variation in informal social control.
} 
Panel Survey. Both datasets were obtained from the Inter-University Consortium for the Political and Social Science Research (ICPSR). The PHDCN was an interdisciplinary study aimed at deepening society's understanding of the causes of juvenile delinquency, adult crime, substance abuse, and violence. Survey data were collected in 1994 from a cross-section of Chicago residents concerning their perceptions of the neighborhood in which they lived. Data collection consisted of 8,782 in-person interviews of residents 18 and older to assess key neighborhood dimensions, including formal and informal social control (see Earls et al., 1999 for an overview). The PHDCN data were collected in groups of census tracts referred to as "neighborhood clusters.” These neighborhood clusters were the result of combining Chicago's 825 populated census tracts into 343 contiguous, demographically-similar areas. The sample was drawn in three stages within the clusters that included city blocks, dwelling units, and adult residents.

Data were also collected for an evaluation of the CAPS program funded by the Illinois Criminal Justice Information Authority (1995; see also Skogan \& Harnett, 1997). The data were collected in 1993 and 1994, and consisted of 1,506 interviews of residents of both the five original CAPS prototype districts and a set of five control districts. In each of the prototype and control police districts that were examined, there were approximately 135 beat meetings—one per beat, per month—during the evaluation period attended by approximately 30.5 people for a total of 4,117 attendees. In CAPS areas, there were extensive efforts to advertise beat meetings, and to attract residents in large numbers. Community newspapers printed beat meeting schedules, and activists posted announcements and placed flyers into residents' mailboxes. While intended to test the success of community policing in Chicago, the original interviews did not test for informal social control. Because both the PHDCN-CS and the CAPS Prototype Panel Survey periods overlapped for one year, 1994, both datasets are used here to 
assess the impact of community policing on informal social control in Chicago by matching and linking the PHDCN census tracts $(n=825)$ with the census tracts of the CAPS prototype and control districts. All total, CAPS was located in 199 of the 825 Chicago census tracts (or, 84 of the 343 neighborhood clusters; 24\%).

Kessler and Duncan (1996) argue that early studies of community policing suffered from weak research designs, in part, because concepts were poorly measured and lacked reliable measures of program implementation. We believe that we overcome these potential validity challenges through the use of fully-vetted data sets. The independent and control variables were taken from the PHDCN. Although originally obtained from existing literature, these variables were subjected to a pilot survey administered to 152 households distributed across a sample of Chicago census tracts (Earls \& Buka, 1997). Subsequent factor analysis determined that the theoretical constructs, as they had been defined, lead to consistent patterns of responses with Eigen values greater than 1.00 and factor loadings greater than .40 (Kaiser, 1974; Kim \& Mueller, 1978), thus ensuring their construct validity (see Table 2).

Moreover, the test areas used in the CAPS Prototype Panel Survey were chosen to represent a cross-section of the city’s racial and ethnic populations: two districts were predominately poor and African-American, one district contained one of the largest concentrations of Hispanics in Chicago, one district was extremely diverse, and one district contained large middle-class white and African-American neighborhoods (Skogan, 2004). Census tract data were then used to select sections of the city that closely matched the demography of the five prototype districts. These “comparison areas” were used to represent what would have happened in the prototype districts if there had not been CAPS. The matching 
factors for selecting the comparison areas were race, ethnicity, home ownership, and the percentage of residents living in buildings of ten or more units.

\section{Measures}

The dependent variable in this study is informal social control. It was obtained from the PHDCN-CS. This concept is generally regarded as the scope of collective intervention that a community directs toward local problems. More specifically, it refers to non-official actions that are taken by community residents to solve neighborhood problems. Here, informal social control is conceptualized as the willingness of neighborhood residents to actively engage in behaviors aimed at preventing crime in their community, with a particular emphasis on controlling the delinquent behavior of neighborhood youth. Examples of informal social control include the monitoring of spontaneous play groups among children, a willingness to intervene to prevent acts such as truancy and street-corner loitering by teenage groups, and the confrontation of persons who are exploiting or disturbing public space (see Sampson et al., 1997). Informal social control was measured using five items from the PHDCN dataset, which asked how likely it was that community residents would do something if they observed deviant activities (e.g., neighbors would do something if a group of neighborhood children skipped school and were hanging out on the street corner). ${ }^{2}$ Each of the five items were measured on a five-point Likert scale from "very unlikely" to "very likely", and the variable demonstrated good internal consistency ( $\alpha=$ .81). This variable had a mean of 3.47 and a standard deviation of 0.93 . For a complete list of variable descriptive statistics and sample characteristics, see Table 1.

\footnotetext{
${ }^{2}$ It should be noted that while similar to the concept of collective efficacy, informal social control is only half of the collective efficacy equation (Ansari, 2013; Sampson et al., 1997). Collective efficacy has often been defined as social cohesion combined with a willingness to intervene on behalf of the community (i.e., informal social control). In a supplemental analysis, we created a collective efficacy measure by combining these two variables. We re-ran the analyses with this new collective efficacy measure as the dependent variable, and the results were substantively similar.
} 
**Insert Table 1 about here**

The independent variable of interest, the presence of CAPS, was obtained from the CAPS prototype Panel Survey. This variable was measured dichotomously ( $0=$ no; $1=$ yes), and this variable indicated whether or not CAPS was being employed in an individual respondent's census tract. Based on our conceptual framework (the community implant hypothesis; Rosenbaum, 1987), we believe that CAPS will have a positive impact on building residents' informal social control.

Several control variables, based on theory and prior research (e.g., Kasarda \& Janowitz, 1974; Lombardo et al., 2010; Sampson \& Groves, 1989; Sampson et al., 1997; Silver \& Miller, 2004; Warner \& Rountree, 1997), obtained from the PHDCN-CS, were utilized in this study. Police satisfaction was measured using a five-item variable from the PHDCN dataset that taps into a respondent's satisfaction with police (e.g., the police in your neighborhood are responsive to local issues). Here, police satisfaction is used as a proxy for government responsiveness as identified by Renauer (2007). The items in this variable $(\alpha=.78)$ were measured on a five-point Likert scale from "strongly disagree" to "strongly agree”. Social disorder $(\alpha=.88)$ refers to the perceived level of disarray and other social nuisances within the neighborhood. It was measured on a three-point Likert scale from "not a problem” to "a big problem” using six items (e.g., how much of a problem is litter, broken glass or trash on sidewalks and streets). Social cohesion $(\alpha=$ .75), the willingness of members of a society to cooperate with each other for the collective good, was measured using five items (e.g., this is a close-knit neighborhood) on a five-point Likert scale from “strongly disagree” to "strongly agree”. Social capital $(\alpha=.78)$ refers to the investment that residents have in their neighborhood. This five-item variable (e.g., residents can count on other adults in the neighborhood to watch out that children are safe and don't get in 
trouble) was measured on a five-point Likert scale from "strongly disagree" to "strongly agree". Neighborhood ties $(\alpha=.80)$ denotes the relational connection between community residents, and it was measured using five items (e.g., how often do you and people in neighborhood do favors for each other) on a four-point Likert scale from "never" to "often”. Finally, Neighborhood activism $(\alpha=.78)$ refers to involvement in community groups or programs. It was measured dichotomously $(0=$ no, 1 = yes) using five items (e.g., attended a block meeting or neighborhood group). Table 2 presents a complete listing of survey items for the PHDCN variables as well as factor analytic information.

\footnotetext{
**Insert Table 2 about here**
}

Additionally, we also control for several demographic and structural variables, which have been utilized in prior research (e.g. Messner, 1982: Sampson, 1987; Sampson \& Groves, 1989; Warner, 2007). Age was measured as number of years old. Sex was measured dichotomously ( 0 = Female, $1=$ Male). Race was measured with two dichotomous variables, Black and Hispanic (White served as the reference group for each). Education was measured as the number of years of schooling. Employment status was measured dichotomously $(0=$ not employed, 1 = employed). Mobility was measured as the number of times the respondent had moved within the last five years. Household income was measured as an ordinal variable with a fifteen response options (e.g., \$20,000-24,999). Home ownership was measured dichotomously $(0=$ rent, $1=$ own $)$. Finally, marital status was measured dichotomously $(0=$ not married, $1=$ married).

Analytic Plan

In the current study, the 8,782 individuals are nested within 343 neighborhood clusters; therefore, multilevel analyses are needed. The analyses herein proceed in three main steps. First, 
bivariate correlations are used to examine the associations between the study variables. Second, a multilevel, mixed effects regression model is estimated to test the community implant hypothesis by examining what effect, if any, CAPS has on informal social control. Based on the multivariate results, a subsequent mediation analysis is employed to test the indirect effect of community policing through police satisfaction.

\section{Results}

Table 3 presents the results of the bivariate correlations between the independent/control variables and the dependent variable. Of particular interest is the positive and significant association between CAPS and informal social control $(r=.03, p<.01)$. Additionally, police satisfaction, social cohesion, social capital, neighborhood ties, neighborhood activism, age, education level, employment status, household income, home ownership, and marital status were all significantly and positively correlated with informal social control. Conversely, social disorder, being Black, and residential mobility were negatively and significantly associated with the outcome variable.

\section{**Insert Table 3 here**}

While the correlation analyses demonstrated that CAPS is significantly associated with increases in informal social control, it was necessary to examine this relationship within a multivariate context. Considering the nested structure of the PHDCN-CS data (e.g., individuals within neighborhood clusters) and the continuous and normally-distributed nature of the dependent variable, it was necessary to use multilevel linear modeling, which enabled the simultaneous estimation of the between- and within-neighborhood differences in residents’ informal social control. Specifically, a multilevel, mixed effects regression model was estimated in STATA 14 using the 'xtmixed' command (Johnson, 2010; Rabe-Hesketh \& Skrondal, 2012). 
In the model, informal social control was regressed on CAPS along with the control variables to provide a test of the community implant hypothesis. ${ }^{3}$ Although CAPS was found to have a bivariate association with informal social control, the multivariate regression model demonstrated that CAPS was statistically unrelated to informal social control after controlling for other relevant variables. This finding does not provide support for Rosenbaum’s (1987) community implant hypothesis.

Police satisfaction, however, was positively related to residents’ informal social control in this model $(\mathrm{B}=.11$, se $=.02, p<.001)$. This result indicates that residents are more likely to intervene on behalf of their community toward solving local problems because they are satisfied with their city’s policing services. Additionally, social cohesion $(\mathrm{B}=.31$, se $=.02, p<.001)$, social capital $(\mathrm{B}=.37$, se $=.02, p<.001)$, neighborhood ties $(\mathrm{B}=.13$, se $=.01, p<.001)$, neighborhood activism $(\mathrm{B}=.03$, se $=.01, p<.001)$, and being Hispanic $(\mathrm{B}=.07, \mathrm{se}=.03, p<$ .01) all predicted increases in residents’ informal social control, whereas social disorder $(\mathrm{B}=$ .23 , se $=.02, p<.001)$ and education $(\mathrm{B}=-.01$, se $=.01, p<.05)$ predicted decreases in residents’ informal social control.

\section{**Insert Table 4 here**}

In light of these findings, a subsequent mediation analysis was conducted to investigate whether the effect of community policing on informal social control was mediated through police satisfaction. This was done as prior research has established that community policing impacts police satisfaction (Weitzer \& Tuch, 2005; Lombardo et al., 2010) and that police satisfaction contributes to informal social control (Renauer, 2007; Silver \& Miller, 2004) A

\footnotetext{
${ }^{3}$ Multicollinearity-statistical associations between the independent variables-can be an issue when estimating multiple regression models. According to Allison (1999), researchers should begin to become concerned when Variance Inflation Factor (VIF) statistics are greater than 2.50. As illustrated by the correlation coefficients in Table 3 and the VIF statistics in Table 4, multicollinearity was not an issue within these analyses.
} 
Sobel-Goodman mediation path analysis was estimated in STATA 14 using the 'sgmediation' command (e.g., Wu \& Zumbo, 2008), and it is presented in Figure 1.

The first part of the model, depicted in the upper-half of Figure 1, demonstrated an initial, direct effect between CAPS and informal social control $(\mathrm{B}=.07$, se $=.02, p<.01)$. However, in looking at the bottom-half of Figure 1, it can be seen that this effect is mediated. The second part of the model revealed a direct effect between CAPS and police satisfaction $(\mathrm{B}=.09$, se $=.02, p<$ .01). Finally, the third part of the model yielded a direct effect between police satisfaction and informal social control $(\mathrm{B}=.52$, se $=.02, p<.001)$ and a mediated effect of CAPS on informal social control, which rendered it non-significant $(\mathrm{B}=.02$, se $=.02$, n.s. $)$. Thus, the mediation effect of police satisfaction was statistically significant with approximately $67 \%$ of the total effect (of CAPS on informal social control) being mediated.

$$
\text { **Insert Figure } 1 \text { here** }
$$

\section{Discussion}

Building on previous research examining the efficacy of policing services (Kerley \& Benson, 2000; Renauer, 2007), the current study tested Rosenbaum’s (1987) community implant hypothesis by examining the predictive utility of community policing (CAPS) in strengthening residents’ informal social control in Chicago. As previously indicated, one of the main arguments offered by researchers to explain the high level of crime besieging many neighborhoods is the lack of informal social control in community areas (e.g., Sampson, 1986). To that end, based on theory and prior research, we hypothesized that informal social control can be embedded by collective citizen action in neighborhoods where community policing strategies are being implemented. To test this assertion, data from the PHDCN and Chicago's CAPS evaluation were analyzed. 
Overall, the results suggest that community policing matters insomuch as it leads to residents' being satisfied with police services. At the bivariate level, there was a positive correlation between CAPS and informal social control, which suggests that residents in CAPS districts had significantly higher levels of informal social control. This result is initially supportive of Rosenbaum's (1987) community implant hypothesis. At the multivariate level, however, the significant effect of community policing was rendered non-significant when controlling for theoretically- and empirically-relevant variables. Subsequently, we found that the CAPS effect on informal social control was mediated through police satisfaction. This lends some indirect support for Rosenbaum’s (1987) community implant hypothesis as community policing initiatives in Chicago were able to increase residents' satisfaction with police services, which led to increases in residents' views of informal social control. These findings are consistent with research from Renauer (2007) and Gill et al. (2014).

Other important findings emerged as well. Consistent with social disorganization theory and research (e.g., Sampson \& Groves, 1989; Shaw \& McKay, 1942; Silver \& Miller, 2004), several social (dis)organization variables (e.g., social disorder and social cohesion) were significant predictors of informal social control. It is also worth noting that both social capital and neighborhood ties were positively related to informal social control. These findings highlight the importance of familiarity, cohesion, and solidarity among community residents. To promote informal social control, these data suggest that community residents need to know one another, communicate with one another, look out for one another, and help each other (Sampson \& Raudenbush, 1999; Silver \& Miller, 2004). Thus, if community policing initiatives are designed and implemented with these outcomes in mind, then community policing should be able to not 
only increase residents' satisfaction with police services, but also contribute to the strengthening of community informal social control (see e.g., Kerley \& Benson, 2000; Silver \& Miller, 2004).

\section{Conclusion}

This study utilized Rosenbaum’s (1987) community implant hypothesis as a conceptual framework to assess whether community policing can increase informal social control in neighborhood areas. Overall, the results provide indirect support for the community implant hypothesis and suggest that community policing matters insofar as it contributes to residents' being satisfied with police services. The findings offer insight into the police-community dynamic, and they yield important policy implications for police administrators and community residents, who both have a vested interest in maintaining order and reducing neighborhood crime.

Although this study makes an important contribution to the literature, the results should be viewed in the context of several limitations. The data are drawn from neighborhoods in a single U.S. city and the study assesses the policing services of a single police department. As community policing philosophies and general policing strategies may differ from agency to agency, it is important for future researchers to replicate these results utilizing other cities and their police departments as our results may not be generalizable to other jurisdictions. For example, Sozer and Merlo (2013) found that community policing has a significant relationship to crime rates in small cities, but not large ones. There may also be some concern regarding the age of the data; however, there has been so little empirical research of the effect of community policing on building informal social control that the data used here are among the best available for this type of analysis. Future research should explore these research questions with newer data as the current data may not fully reflect the tenants of modern community policing. 
The data are cross-sectional in nature, and, thus, definitive conclusions cannot be reached concerning the causal linkage between the predictor and outcome variables. Future research may want to consider a prospective, longitudinal methodology to fully understand the relationship between policing services and informal social control. Community policing was also measured only as the presence or absence of CAPS within a census tract. Thus, the results are not able to delineate the effectiveness (or ineffectiveness) of specific policies and strategies within the CAPS program. Moreover, the current data do not provide information on whether people in the CAPS areas were actually exposed to, or involved in, CAPS efforts. Future research could build on this study by collecting data on the efficacy of particular community policing mechanisms (e.g., beat meetings vs. foot patrol vs. community mobilization) as well as the immersion level of residents in the community policing initiatives.

Despite these limitations, the results of this study yield meaningful policy implications for how residents can strengthen their informal social control efforts, and how the police might be able to play a part in this effort. It has been well documented that community policing has little effect on reducing crime and disorder (e.g., Crowl, 2017; Weisburd \& Eck, 2004; Rosenbaum, 1987; Wycoff \& Skogan, 1993); however, the current results indirectly support the ability of community policing to reduce crime and disorder through informal social control. The current findings suggest that residents have higher levels of informal social control when they are satisfied with policing services, and that satisfaction can be strengthened through community policing initiatives. Thus, police administrators can implement community policing policies, but should also be directing resources to fully maximize the department's responsiveness in dealing with local issues and crime problems (e.g., Williams, 2003). 
While not directly addressed here, intelligence-led policing and successful problemoriented policing strategies could provide mechanisms for successfully responding to crime problems thus increasing satisfaction with police (e.g., Sozer \& Merlo, 2013). These findings support Gill et al. (2014), who argue that the effectiveness of community policing is subject to a “causal ordering” in which people must be satisfied with the police before the program can impact crime and fear of crime, which are longer-term outcomes.

Moreover, a police department’s responsiveness can not only make residents more satisfied with policing services, responsiveness can also increase the legitimacy that residents feel for the police (Skogan, 2005; Tyler, 2002), increase cooperation with the police (Tyler \& Fagan, 2008), and make residents more inclined to help the police fight crime in their communities (Tyler \& Fagan, 2008). In fact, enhancing legitimacy and cooperation was one of the main pillars advanced in the final report of the President's Task Force on $21^{\text {st }}$ Century Policing. Thus, by increasing satisfaction with — and strengthening the legitimacy of — the police, the capacity and resolve of community residents to prevent and control crime may be reinforced.

Beyond a police administrator's task of increasing the satisfaction and legitimacy that the community feels for its police, the current study's findings also yield other policy and practice recommendations, which focus on the solidification of social cohesion, social capital, and neighborhood ties (see e.g., Silver \& Miller, 2004). Community residents are much more likely to act on behalf of the neighborhood when they feel a sense of cohesiveness among their neighbors and when they are willing to intervene for the common good. This willingness often depends, in large part, on the strength of community investment, mutual trust, and neighborhood solidarity (Sampson et al., 1997). Thus, to increase informal social control, residents and neighborhood groups, possibly in conjunction with local community policing strategies, might 
organize trash cleanup days, mobilize to influence local politicians to obtain needed resources, work together to attract jobs, participate in local community events, join neighborhood watch programs, attend block parties, and participate in neighborhood gentrification projects. 


\section{References}

Ansari, S. (2013). Social capital and collective efficacy: Resource and operating tools of community social control. Journal of Theoretical \& Philosophical Criminology, 5(2), 7594.

Bowers, W. J., \& Hirsch, J. H. (1987). The impact of foot patrol staffing on crime and disorder In Boston: An unmet promise. American Journal of Police, 6(1), 17-44.

Brown, L. P., \& Wycoff, M. A. (1987). Policing Houston: Reducing fear and improving service. Crime and Delinquency, 33(1), 71-89.

Chicago Community Policing Evaluation Consortium. (1995). Community policing in Chicago, year two: an interim report. Chicago, IL: Illinois Criminal Justice Information Authority. Chicago Community Policing Evaluation Consortium. (2004). Community policing in Chicago year ten. Chicago, IL: Illinois Criminal Justice Information Authority.

Crowl, J. N. (2017). The effect of community policing on fear and crime reduction, police legitimacy and job satisfaction: an empirical review of the evidence. Police Practice and Research, 18(5), 449-462.

Davis, R., Henderson, N., \& Merrick, C. (2003). Community policing: Variations on the western model in the developing world. Police Practice and Research, 4(3), 285-300.

Department of Justice (2016). The COPS Office. Retrieved from http://www.cops.usdoj.gov/Default.asp?Item=2754

Earls, F. (1994). Project on human development in Chicago neighborhoods: Community survey, 1994-1995 [Computer file]. ICPSR version. Boston, MA: Harvard Medical School [producer].

Earls, F., \& Burka, S. (1997). Project on human development in Chicago neighborhoods: 
Technical report. Washington, DC: National Institute of Justice.

Evans, W., \& Owens, E. (2007). COPS and crime. Journal of Public Economics, 91, 181-201.

Gill, C., Weisburd, D., Telep, C., \& Bennett, T. (2014). Community-oriented policing to reduce crime, disorder, and fear and increase satisfaction and legitimacy among citizens: A systematic review. Journal of Experimental Criminology, 10(4): 399-428.

Institute for Public Policy Research (2016). Community policing evaluation. Evanston IL: Northwestern University. DOI: http://www.ipr.northwestern.edu/facultyexperts/fellows/community-policing.html\#1.

Johnson, B. (2010). Multilevel analysis in the study of crime and justice. In A. R. Piquero \& D. Weisburd (Eds.), The handbook of quantitative criminology (pp. 615-648). New York: Springer.

Kaiser, H. F. (1974). An index of factorial simplicity. Psychometrika, 39(1), 31-36.

Kerley, K. R., \& Benson, M. L. (2000). Does community-oriented policing help build stronger communities? Police Quarterly, 3(1), 46-69.

Kerlikowske, R. (2004, April). The end of community policing: Remembering the lessons learned. FBI Law Enforcement Bulletin.

Kim, J., \& Mueller, C. W. (1978). Introduction to factor analysis. Newbury Park, CA: Sage.

Lombardo, R., \& Lough, T. (2007). Community policing: Broken windows, community building, and satisfaction with the police. The Police Journal, 80(2), 117-140.

Lombardo, R., Olson, D., \& Stanton, M. (2010). The Chicago Alternative Policing Strategy: A reassessment of the CAPS program. Policing: An International Journal of Police Strategies and Management, 33(4), 586-6-6. 
Lyons, W. (1999). The politics of community policing: Rearranging the power to punish. Ann Arbor, MI: University of Michigan Press.

MacDonald, J. (2002). The effectiveness of community policing in reducing violence. Crime \& Delinquency, 48(4), 592-618.

Marks, M., Shearing, C., \& Wood, J. (2009). Who should the police be? Finding a new narrative for community policing in South Africa. Police Practice and Research, 10(2), 145-155.

Mastrofski, S. D., \& Ritti, R. R. (2000). Making sense of community policing: A theory-based analysis. Police Practice and Research, 1(2), 183-210.

Mastrofski, S. Worden, S., \& Snipes, J. (1995). Law enforcement in a time of community policing. Criminology, 33(4), 539-563.

Messner, S. (1982). Poverty, inequality, and the urban homicide rate. Criminology, 20(1) 103114.

Oliver, W. (2000). The third generation of community policing: Moving through innovation, diffusion, and institutionalization. Police Quarterly, 3(4), 367-388.

President's Task force on $21^{\text {st }}$ Century Policing (2015). Final report of the president's task force on $21^{\text {st }}$ century policing. Washington DC: Office of Community Oriented Policing Services.

Rabe-Hesketh, S., \& Skrondal, A. (2012). Multilevel and longitudinal modeling using Stata. College Station, TX: Stata Press.

Renauer, B. (2007). Is neighborhood policing related to informal social control? Policing: An International Journal of Police Strategies and Management, 30(1), 61-81.

Reisig, M. D., \& Parks, R. B. (2004). Can community policing help the truly disadvantaged? Crime and Delinquency, 50(2), 139-167. 
Rosenbaum, D. P. (1987). The theory and research behind neighborhood watch: Is it a sound fear and crime reduction strategy? Crime and Delinquency, 33(1), 103-134.

Sampson, R. J. (1986). Crime in cities: The effects of formal and informal social control. Crime and Justice, 8, 271-311.

Sampson, R. (1987). Urban black violence: The effect of male joblessness and family disruption. American Journal of Sociology, 93(2), 348-382.

Sampson, R., Raudenbush S., \& Earls, F. (1997). Neighborhoods and violent crime: A multilevel study of collective efficacy. Science, 277(5328), 918-924.

Sampson, R., \& Groves, W. B. (1989). Community structure and crime: Testing social disorganization theory. American Journal of Sociology, 94(4), 774-802.

Sampson, R. J., \& Raudenbush, S. W. (1999). Systematic social observation of public spaces: A new look at disorder in urban neighborhoods. American Journal of Sociology, 105(3), 603-651.

Scheider, M., Chapman, R. \& Schapiro, A. (2009). Towards the unification of policing innovations under community policing. Policing: An International Journal of Police Strategies \& Management, 32(4), 694-718.

Scott, J. (2002). Assessing the relationship between police-community coproduction and neighborhood-level social capital. Journal of Contemporary Criminal Justice, 18(2), 147166.

Shaw, C., \& McKay, H. (1942). Juvenile delinquency in urban areas. Chicago, IL: University of Chicago Press.

Silver, E., \& Miller, L. (2004). Sources of informal social control in Chicago neighborhoods. Criminology, 42(3), 551-582. 
Skogan, W. (1990). Disorder and decline: Crime and the spiral of decay in American neighborhoods. New York, NY: Free Press.

Skogan, W. (1995). Community participation and community policing. Paper presented to Workshop on Evaluating Police Service Delivery, Sponsored by the University of Montreal and Solicitor General of Canada. DOI http://www.ipr.northwestern.edu/publications/papers/urban-policy-and-communitydevelopment/docs/caps/caps4.pdf.

Skogan, W. (2004). Community policing: Can it work? Belmont, CA: Wadsworth.

Skogan, W. (2004). Longitudinal Evaluation of Chicago's Community Policing Program 19932001 [Computer file]. 2nd ICPSR version. Chicago IL: Northwestern University [producer]. Ann Arbor MI: Inter-university Consortium for Political and Social Research [distributor].

Skogan, W. (2005). Citizen satisfaction with police encounters. Police Quarterly, 8(3), 298321.

Skogan W., \& Frydl, K. (2004.) Fairness and effectiveness in policing: The evidence. National Academy of Sciences. Washington, DC: National Academy Press.

Skogan, W., \& Hartnett, S. (1997). Community policing: Chicago style. New York: Oxford University Press.

Sozer, M., \& Merlo, A. (2013). The impact of community policing on crime rates: Does the effect of community policing differ in large and small law enforcement agencies? Police Practice and Research. 14(6), 506-521.

Trojanowicz, R., Kappeler, V. E., Gaines, L. K., \& Bucqueroux, B. (1998). Community policing: A contemporary perspective. Cincinnati, $\mathrm{OH}$ : Anderson. 
Tyler, T. R. (2002). A national survey for monitoring police legitimacy. Justice Research and Policy, 4(1-2), 71-86.

Tyler, T. R., \& Fagan, J. (2008). Legitimacy and cooperation: Why do people help the police fight crime in their communities? Ohio State Journal of Criminal Law, 6, 231-276.

Warner, B. D. (2007). Directly intervene or call the authorities? A study of forms of neighborhood social control within a social disorganization framework. Criminology, 45(1), 99-129.

Warner, B. D. (2014). Neighborhood factors related to the likelihood of successful informal social control efforts. Journal of Criminal Justice, 42(5), 421-430.

Warner, B., \& Rountree, P. (1997). Social ties and crime: Is the relationship gendered? Criminology, 37(4), 789-814.

Weisburd, D., \& Eck, J. E. (2004). What can police do to reduce crime, disorder, and fear? The Annals of the American Academy of Political and Social Science, 593(1), 42-65.

Weitzer, R., \& Tuch, S. A. (2005). Determinants of public satisfaction with the police. Police Quarterly, 8(3), 279-297.

Williams, E. J. (2003). Structuring in community policing: Institutionalizing innovative change. Police Practice and Research, 4(2), 119-129.

Wilson, W. (1987). The Truly Disadvantaged. Chicago, IL: The University of Chicago Press.

Wu, A. D., \& Zumbo, B. D. (2008). Understanding and using mediators and moderators. Social Indicators Research, 87(3), 367-392.

Wycoff, M. A., \& Skogan, W. G. (1993). Quality policing in Madison: An evaluation of its implementation and impact. Washington, DC: The Police Foundation. 
Table 1: Descriptive statistics

\begin{tabular}{|l|c|c|c|c|}
\hline Variable & $\underline{\underline{\mathbf{M}}}$ / $\underline{\underline{\text { O }}}$ & $\underline{\underline{\text { D }}}$ & $\underline{\underline{\text { Min }}}$ & $\underline{\underline{\text { Max }}}$ \\
\hline & & & & \\
\hline Dependent Variable & & & & \\
\hline Informal Social Control & 3.47 & 0.93 & 1.00 & 5.00 \\
\hline & & & & \\
\hline Independent Variables & & & & \\
\hline CAPS (1 = yes) & $24 \%$ & -- & 0.00 & 1.00 \\
\hline & & & & \\
\hline Control Variables & & & & \\
\hline Social Disorder & 1.80 & 0.63 & 1.00 & 3.00 \\
\hline Police Satisfaction & 3.12 & 0.63 & 1.00 & 5.00 \\
\hline Social Cohesion & 3.37 & 0.68 & 1.00 & 5.00 \\
\hline Social Capital & 3.53 & 0.65 & 1.00 & 5.00 \\
\hline Neighborhood Ties & 2.51 & 0.74 & 1.00 & 4.00 \\
\hline Neighborhood Activism & 1.14 & 1.52 & 0.00 & 5.00 \\
\hline Age & 42.66 & 16.72 & 18.00 & 100.00 \\
\hline Sex (1 = male) & $41 \%$ & -- & 0.00 & 1.00 \\
\hline Black & $40 \%$ & -- & 0.00 & 1.00 \\
\hline Hispanic & $25 \%$ & -- & 0.00 & 1.00 \\
\hline Education & 12.31 & 3.12 & 0.00 & 17.00 \\
\hline Employment (1= yes) & $58 \%$ & -- & 0.00 & 1.00 \\
\hline Mobility & 0.95 & 1.37 & 0.00 & 11.00 \\
\hline Income (median category) & 5.00 & -- & 1.00 & 15.00 \\
\hline Home Ownership (1 = yes) & $45 \%$ & -- & 0.00 & 1.00 \\
\hline Marital Status (1 = yes) & $37 \%$ & -- & 0.00 & 1.00 \\
\hline Nore: The fift can & $37 \%$ & & \\
\hline
\end{tabular}

Note: The fifth category for Income is "\$20,000 - 24,999" 
Table 2: Factor analyses of PHDCN variables

\begin{tabular}{|c|c|c|}
\hline Variable/Item & Eigenvalue & Factor Loading \\
\hline Informal Social Control (Cronbach’s $\alpha=.81)$ & 2.58 & \\
\hline $\begin{array}{l}\text { Neighbors would do something if a group of neighborhood children skipped school and were hanging out on } \\
\text { the street corner. }\end{array}$ & & .828 \\
\hline Neighbors would do something if children spray-painted graffiti on a local building. & & .824 \\
\hline People in the neighborhood would scold a child if the child showed disrespect to an adult. & & .806 \\
\hline Neighbors would break up a fight in front of your house where someone was being beaten or threatened. & & .752 \\
\hline Police Satisfaction (Cronbach's $\alpha=.78$ ) & 2.71 & \\
\hline The police in your neighborhood are responsive to local issues. & & .828 \\
\hline The police are doing a good job in dealing with problems that really concern people in your neighborhood. & & .865 \\
\hline The police are not doing a good job in preventing crime in neighborhood. [R] & & .683 \\
\hline The police do a good job in responding to people in neighborhood after being victims of crime. & & .663 \\
\hline The police are not able to maintain order on streets and sidewalks in your neighborhood. [R] & & .604 \\
\hline Social Disorder (Cronbach’s $\alpha=.88)$ & 3.80 & \\
\hline How much of a problem is litter, broken glass or trash on sidewalks and streets? & & .790 \\
\hline How much of a problem is graffiti on buildings and walls? & & .750 \\
\hline How much of a problem are vacant or deserted houses or storefronts? & & .741 \\
\hline How much of a problem is drinking in public? & & .830 \\
\hline How much of a problem is people selling or using drugs? & & .844 \\
\hline How much of a problem is groups of teenagers or adults hanging out in the neighborhood and causing trouble? & & .811 \\
\hline Social Cohesion (Cronbach's $\alpha=.75)$ & 2.52 & \\
\hline This is a close-knit neighborhood. & & .732 \\
\hline People around here are willing to help their neighbors. & & .803 \\
\hline People in the neighborhood generally don't get along with each other. [R] & & .628 \\
\hline People in the neighborhood don't share the same values. [R] & & .592 \\
\hline People in the neighborhood can be trusted. & & .770 \\
\hline Social Capital (Cronbach's $\alpha=.78)$ & 2.70 & \\
\hline There are adults in this neighborhood that children can look up to. & & .654 \\
\hline $\begin{array}{l}\text { Residents can count on other adults in the neighborhood to watch out that children are safe and don't get in } \\
\text { trouble. }\end{array}$ & & .735 \\
\hline Parents in the neighborhood know their children’s friends. & & .755 \\
\hline Adults in the neighborhood know who the local children are. & & .756 \\
\hline
\end{tabular}




\begin{tabular}{|c|c|c|}
\hline Parents in the neighborhood generally know each other. & & .769 \\
\hline Neighborhood Ties (Cronbach’s $\alpha=.80)$ & 2.81 & \\
\hline How often do you and people in neighborhood do favors for each other? & & .807 \\
\hline When a neighbor is not at home, how often do you and other neighbors watch over their property? & & .721 \\
\hline How often do you and other people in the neighborhood ask each other advice about personal things? & & .745 \\
\hline $\begin{array}{l}\text { How often do you and people in the neighborhood have get-togethers where other people in neighborhood are } \\
\text { invited? }\end{array}$ & & .697 \\
\hline How often do you and people in the neighborhood visit in each other’s homes or on the street? & & .770 \\
\hline Neighborhood Activism (Cronbach's $\alpha=.78$ ) & 2.67 & \\
\hline $\begin{array}{l}\text { Have you (or any household member) spoken with a local politician or an elected local official about a } \\
\text { neighborhood problem? }\end{array}$ & & .737 \\
\hline Have you (or any household member) talked to a person or group causing a problem in the neighborhood? & & .650 \\
\hline $\begin{array}{l}\text { Have you (or any household member) attended a block meeting or neighborhood group meeting about a } \\
\text { neighborhood problem or neighborhood improvement? }\end{array}$ & & .812 \\
\hline $\begin{array}{l}\text { Have you (or any household member) talked to a local religious leader or minister to help with a } \\
\text { neighborhood problem or with neighborhood improvement? }\end{array}$ & & .623 \\
\hline $\begin{array}{l}\text { Have you (or any household member) gotten together with neighbors to do something about a neighborhood } \\
\text { problem or to organize neighborhood improvement? }\end{array}$ & & .813 \\
\hline
\end{tabular}

Note: $[\mathrm{R}]=$ reverse coded 
Table 3: Bivariate correlations among study variables

\begin{tabular}{|c|c|c|c|c|c|c|c|c|c|c|c|c|c|c|c|c|c|c|}
\hline & 1 & 2 & 3 & 4 & 5 & 6 & 7 & 8 & 9 & 10 & 11 & 12 & 13 & 14 & 15 & 16 & 17 & 18 \\
\hline V1 & -- & & & & & & & & & & & & & & & & & \\
\hline V2 & $.03^{* *}$ & -- & & & & & & & & & & & & & & & & \\
\hline V3 & $.35 * *$ & $-.06 * *$ & -- & & & & & & & & & & & & & & & \\
\hline V4 & $-.37 * *$ & $.11^{* *}$ & $-.50 * *$ & -- & & & & & & & & & & & & & & \\
\hline V5 & $.55 * *$ & $-.04 * *$ & $.42 * *$ & $-.43 * *$ & -- & & & & & & & & & & & & & \\
\hline V6 & $.52 * *$ & $-.04 * *$ & $.33^{* *}$ & $-.28 * *$ & $.63 * *$ & -- & & & & & & & & & & & & \\
\hline V7 & $.39 * *$ & $-.04 * *$ & $.22 * *$ & $-.14 * *$ & $.48 * *$ & $.48 * *$ & -- & & & & & & & & & & & \\
\hline V8 & $.20 * *$ & .01 & $.07 * *$ & .01 & $.22^{* *}$ & $.23 * *$ & $.36 * *$ & -- & & & & & & & & & & \\
\hline V9 & $.08 * *$ & -.01 & $.13^{* *}$ & $-.13 * *$ & $.14^{* *}$ & $.08 * *$ & $.04 * *$ & $.13^{* *}$ & -- & & & & & & & & & \\
\hline V10 & .01 & -.02 & $.03 *$ & $-.03 *$ & $.03 *$ & -.01 & $.04 * *$ & .01 & $-.04 * *$ & -- & & & & & & & & \\
\hline V11 & $-.09 * *$ & $.20^{* *}$ & $-.13 * *$ & $.16^{* *}$ & $-.11 * *$ & -.01 & $-.04 * *$ & .01 & $.05^{* *}$ & $-.06 * *$ & -- & & & & & & & \\
\hline V12 & -.02 & $-.03 *$ & $-.11 * *$ & $.10^{* *}$ & $-.07 * *$ & $-.07 * *$ & $-.07 * *$ & $-.11 * *$ & $-.20 * *$ & $.04 * *$ & $-.47 * *$ & -- & & & & & & \\
\hline V13 & $.06^{* *}$ & $-.05 * *$ & $.16^{* *}$ & $-.16 * *$ & $.10^{* *}$ & $.05^{* *}$ & $.10^{* *}$ & $.16^{* *}$ & $-.19 * *$ & $.04^{* *}$ & $.03^{* *}$ & $-.34 * *$ & -- & & & & & \\
\hline V14 & $.05^{* *}$ & $-.03 *$ & $.08 * *$ & $-.09 * *$ & $.07 * *$ & .01 & .03* & $.06^{* *}$ & $-.29 * *$ & $.20 * *$ & $-.10 * *$ & $.04^{* *}$ & $.29 * *$ & -- & & & & \\
\hline V15 & $-.10 * *$ & $-.06 * *$ & $-.03 *$ & $.04 * *$ & $-.11 * *$ & $-.15^{* *}$ & $-.14 * *$ & $-.18 * *$ & $-.35 * *$ & $.03 * *$ & $-.12 * *$ & $.07 * *$ & $.08 * *$ & $.07 * *$ & -- & & & \\
\hline V16 & $.19 * *$ & $-.06 * *$ & $.24 * *$ & $-.29 * *$ & $.27 * *$ & $.12^{* *}$ & $.16^{* *}$ & $.22 * *$ & $-.07 * *$ & $.14^{* *}$ & $-.20 * *$ & $-.11 * *$ & $.42^{* *}$ & $.45^{* *}$ & $-.05 * *$ & -- & & \\
\hline V17 & $.18^{* *}$ & .02 & $.13 * *$ & $-.17 * *$ & $.24 * *$ & $.19 * *$ & $.20 * *$ & $.28 * *$ & $.27 * *$ & .02 & $-.07 * *$ & $-.06 * *$ & $.08 * *$ & $.05^{* *}$ & $-.34 * *$ & $.38 * *$ & -- & \\
\hline V18 & $.08 * *$ & .01 & $.04^{* *}$ & $-.08 * *$ & $.10 * *$ & $.07 * *$ & $.09 * *$ & $.10 * *$ & $.08 * *$ & $.06 * *$ & $-.17 * *$ & $.16^{* *}$ & $-.07 * *$ & $.08 * *$ & $-.10 * *$ & $.27 * *$ & $.24 * *$ & -- \\
\hline
\end{tabular}

Note: V1 = Informal Social Control; V2 = CAPS; V3 = Police Satisfaction; V4 = Social Disorder; V5 = Social Cohesion; V6 = Social Capital; V7 =

Neighborhood Ties; V8 = Neighborhood Activism; V9 = Age; V10 = Sex; V11 = Black; V12 = Hispanic; V13 = Education Level; V14 = Employment Status;

V15 = Residential Mobility; V16 = Household Income; V17 = Own Home; V18 = Marital Status

$* p<.05 * * p<.01$ 
Table 4: Multilevel, mixed effects linear regression model predicting informal social control

\begin{tabular}{|c|c|c|c|c|}
\hline Variable & & & & \\
\hline & B & SE & $\mathrm{Z}$ & VIF \\
\hline CAPS & .02 & .02 & .60 & 1.06 \\
\hline Police Satisfaction & $.11^{* * *}$ & .02 & 6.26 & 1.50 \\
\hline Social Disorder & $-.23 * * *$ & .02 & -12.97 & 1.56 \\
\hline Social Cohesion & $.31 * * *$ & .02 & 17.17 & 2.18 \\
\hline Social Capital & $.37 * * *$ & .02 & 19.95 & 1.88 \\
\hline Neighborhood Ties & $.13 * * *$ & .01 & 9.43 & 1.47 \\
\hline Neighborhood Activism & $.03 * * *$ & .01 & 4.74 & 1.23 \\
\hline Age & -.01 & .01 & -1.68 & 1.45 \\
\hline Sex & -.03 & .02 & -1.88 & 1.05 \\
\hline Black & -.03 & .02 & -.89 & 1.54 \\
\hline Hispanic & $.07^{* *}$ & .03 & 2.67 & 1.67 \\
\hline Education & $-.01 *$ & .01 & -2.11 & 1.53 \\
\hline Employed & .02 & .02 & 1.06 & 1.42 \\
\hline Income & .01 & .01 & -.75 & 1.91 \\
\hline Residential Mobility & -.01 & .01 & -.83 & 1.28 \\
\hline Own Home & .03 & .02 & .90 & 1.45 \\
\hline Married & -.01 & .02 & -.78 & 1.19 \\
\hline & \multicolumn{4}{|c|}{ Model Information } \\
\hline -2 Restricted Log Likelihood & \multicolumn{4}{|c|}{15821.52} \\
\hline Wald $\chi^{2}$ & \multicolumn{4}{|c|}{$4304.55_{(17)} * * *$} \\
\hline
\end{tabular}


Figure 1: Direct and indirect relationships between community policing, police satisfaction, and informal social control.

Initial Direct Effect

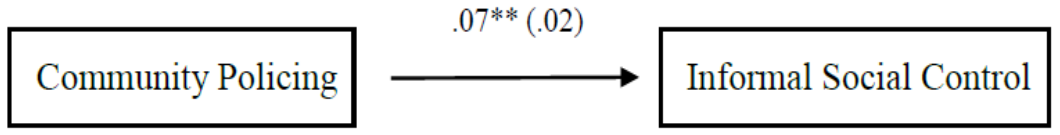

Partial Direct and Mediation Effects

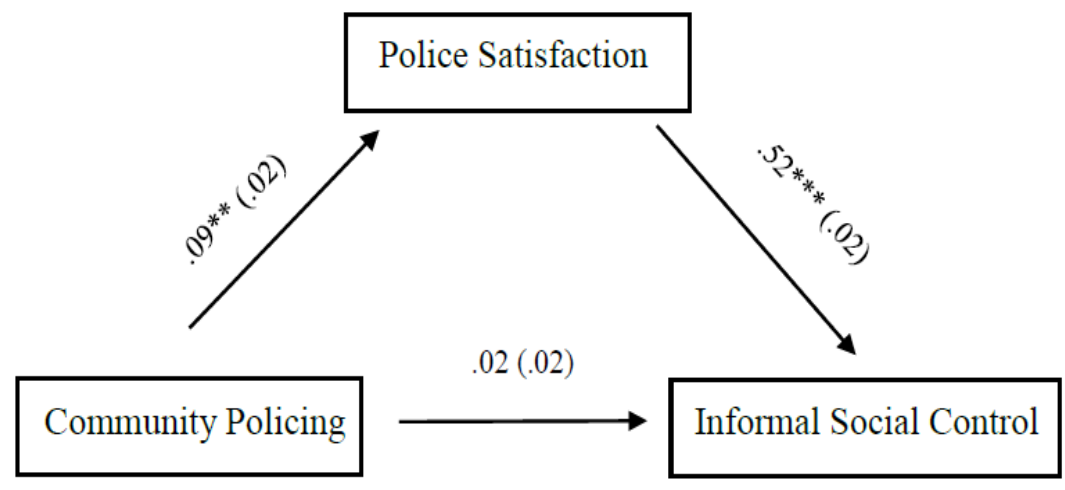

$$
* p<.05 * * p<.01 * * * p<.001
$$

